\title{
Eriodictyol attenuates arsenic trioxide-induced liver injury by activation of Nrf2
}

\author{
Guanghong Xie ${ }^{1, *}$, Xiaolin Meng ${ }^{1, *}$, Fei Wang ${ }^{1}$, Yuxin Bao ${ }^{1}$ and Junyuan Huo ${ }^{1}$ \\ ${ }^{1}$ College of Veterinary Medicine, Jilin University, Changchun 130062, China \\ *These authors have contributed equally to this work \\ Correspondence to: Guanghong Xie, email: Xiegh@jlu.edu.cn
}

Keywords: eriodictyol, arsenic trioxide, liver injury, Nrf2

Received: March 29, $2017 \quad$ Accepted: June 28, $2017 \quad$ Published: August 02, 2017

Copyright: Xie et al. This is an open-access article distributed under the terms of the Creative Commons Attribution License 3.0 (CC BY 3.0), which permits unrestricted use, distribution, and reproduction in any medium, provided the original author and source are credited.

\section{ABSTRACT}

Arsenic, a well-known human carcinogen, has been reported to induce hepatic oxidative stress and hepatic injury. Eriodictyol, a flavonoid found in citrus fruits, has been reported to have antioxidant effects. In this study, we aimed to investigate the protective effects of eriodictyol on arsenic trioxide $\left(\mathrm{As}_{2} \mathrm{O}_{3}\right)$-induced liver injury and to clarify the molecular mechanism. Male Wistar rats were administrated $3 \mathrm{mg} / \mathrm{kg}$ $\mathrm{As}_{2} \mathrm{O}_{3}$ intravenous injection at days 1, 4, 5, and 7. Eriodictyol was given $1 \mathrm{~h}$ before or after $\mathrm{As}_{2} \mathrm{O}_{3}$ treatment. The results showed that eriodictyol prevented $\mathrm{As}_{2} \mathrm{O}_{3}$-induced liver reactive oxygen species (ROS) and malonaldehyde (MDA) levels. Eriodictyol abrogated $\mathrm{As}_{2} \mathrm{O}_{3}$-induced decrease of the antioxidant enzymes superoxide dismutase (SOD), glutathione peroxidase (GPX), and catalase (CAT) activity. Eriodictyol also attenuated $\mathrm{As}_{2} \mathrm{O}_{3}$-induced hepatic pathological damage. In addition, eriodictyol promoted the expression of nuclear factor erythroid 2 p45 related factor 2 ( Nrf2) and heme oxygenase-1 (HO-1) up-regulated by $\mathrm{As}_{2} \mathrm{O}_{3}$. In conclusion, our results demonstrated that eriodictyol exhibited a protective effect on $\mathrm{As}_{2} \mathrm{O}_{3}$-induced liver injury and the possible mechanism is involved in activating Nrf2 signaling pathway.

\section{INTRODUCTION}

Arsenic, a well known cytotoxic environmental toxicant, is present in soil, drinking water, and food [1]. Arsenic exposure causes various hazardous effects in human including carcinogenesis in lungs, livers, and bladders [2,3]. Previous studies showed that arsenicinduced oxidative stress is the main reason of arsenicinduced carcinogenesis [4]. Liver is the major target organ of arsenic. Arsenic-induced liver injury is closely associated with oxidative stress and previous reports indicated that antioxidants had therapeutic effects against arsenic-induced liver injury $[5,6]$. Nrf2, an important transcription factor, has been demonstrated to play critical roles in cellular defense against oxidative stress [7]. Activating of Nrf2 had the ability to protect against arsenic-induced liver injury [8].

Eriodictyol, a flavonoid found in citrus fruits, has been reported to have anti-inflammatory, anti-apoptotic, and antioxidant effects. Eriodictyol has been reported to prevent early retinal and plasma abnormalities in streptozotocin-induced diabetic rats [9]. Eriodictyol also protected against hydrogen peroxide-induced neurotoxicity in cultured rat pheochromocytoma cells [10]. Furthermore, eriodictyol was found to exhibit antioxidant effect on UVinduced apoptosis in keratinocytes [11]. However, the protective effects and molecular mechanism of eriodictyol on arsenic trioxide-induced liver injury remain unclear. In this study, we sought to determine whether eriodictyol had protective effects on arsenic trioxide-induced liver injury in rats.

\section{RESULTS}

Effects of eriodictyol on $\mathrm{As}_{2} \mathrm{O}_{3}$-induced liver histopathologic changes

To investigate the protective effects of eriodictyol on $\mathrm{As}_{2} \mathrm{O}_{3}$-induced liver injury, histopathological changes of liver tissues were tested by H\&E staining. As shown in 
Figure 1, liver histological sections of control group and eriodictyol alone group showed normal structures. Liver histological sections of $\mathrm{As}_{2} \mathrm{O}_{3}$-treated mice showed serious pathological changes, such as extensive areas of portal inflammation, cellular necrosis, and inflammatory cells infiltration. However, $\mathrm{As}_{2} \mathrm{O}_{3}$-induced liver histopathologic changes were markedly ameliorated by treatment of eriodictyol.

\section{Effects of eriodictyol on ROS and MDA levels in liver tissues}

To investigate the anti-oxidative effects of eriodictyol, the effects of eriodictyol on $\mathrm{As}_{2} \mathrm{O}_{3}$-induced ROS and MDA levels were detected. As shown in Figure 2, treatment of eriodictyol alone did not affect the levels of ROS and MDA. The levels of ROS and MDA increased significantly of $\mathrm{As}_{2} \mathrm{O}_{3}$-treated group than that of the control group. However, in $\mathrm{As}_{2} \mathrm{O}_{3}$ + eriodictyol treated group, the levels of $\mathrm{ROS}$ and MDA in liver tissues decreased significantly than that of the $\mathrm{As}_{2} \mathrm{O}_{3}$-treated group.

\section{Effects of eriodictyol on SOD, GPX, and CAT activity in liver tissues}

The effects of eriodictyol on antioxidant enzymes SOD, GPX, and CAT activity were also detected in this study. The results showed that treatment of eriodictyol alone did not affect the activity of SOD, GPX, and CAT. $\mathrm{As}_{2} \mathrm{O}_{3}$ significantly inhibited the activity of antioxidant enzymes SOD, GPX, and CAT. However, the inhibition of SOD, GPX, and CAT activity by $\mathrm{As}_{2} \mathrm{O}_{3}$ was abrogated by eriodictyol (Figure 3).

\section{Effects of eriodictyol on $\mathrm{As}_{2} \mathrm{O}_{3}$-induced ALT and AST levels in serum}

The effects of eriodictyol on $\mathrm{As}_{2} \mathrm{O}_{3}$-induced ALT and AST levels in serum were detected in this study. As shown in Figure 4, treatment of eriodictyol alone did not affect the levels of ALT and AST. The levels of ALT and AST increased significantly of $\mathrm{As}_{2} \mathrm{O}_{3}$-treated group than that of the control group. However, eriodictyol significantly inhibited $\mathrm{As}_{2} \mathrm{O}_{3}$-induced ALT and AST levels.

\section{Eriodictyol promoted the expression of Nrf2 and HO-1}

To investigate the anti-oxidative mechanism of eriodictyol, the effects of eriodictyol on Nrf2 and HO-1 expression were measured by qRT-PCR and western blot analysis. The results showed that the mRNA and protein expression of Nrf2 and HO-1 were increased by treatment of $\mathrm{As}_{2} \mathrm{O}_{3}$. However, eriodictyol up-regulated the expression of Nrf2 and $\mathrm{HO}-1$ induced by $\mathrm{As}_{2} \mathrm{O}_{3}$ (Figure 5). Furthermore, treatment of eriodictyol alone could
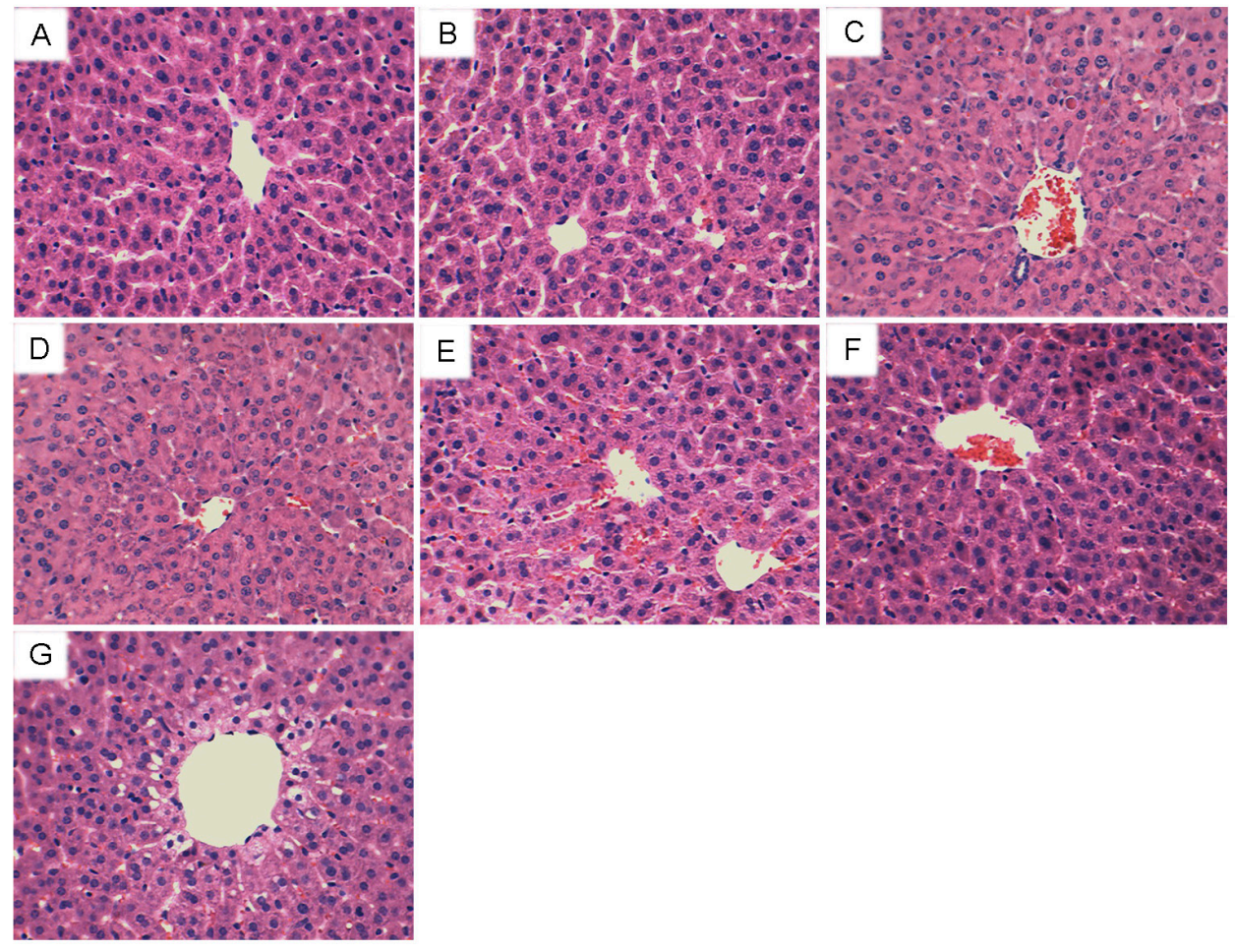

Figure 1: Effects of eriodictyol on $\mathrm{As}_{2} \mathrm{O}_{3}$-induced liver histopathologic changes. Representative histological changes of liver obtained from rats of different groups. (A): Control group, (B): eriodictyol (40mg/kg) group, (C): $\mathrm{As}_{2} \mathrm{O}_{3}$ group, (D): eriodictyol (10mg/kg) $+\mathrm{As}_{2} \mathrm{O}_{3}$ group, (E): eriodictyol $(20 \mathrm{mg} / \mathrm{kg})+\mathrm{As}_{2} \mathrm{O}_{3}$ group, (F): eriodictyol $(40 \mathrm{mg} / \mathrm{kg})+\mathrm{As}_{2} \mathrm{O}_{3}$ group, (G): eriodictyol $(40 \mathrm{mg} / \mathrm{kg})+\mathrm{As} \mathrm{O}_{3}$ group ( $1 \mathrm{~h}$ after) (Hematoxylin and eosin staining, magnification $200 \times)$. 

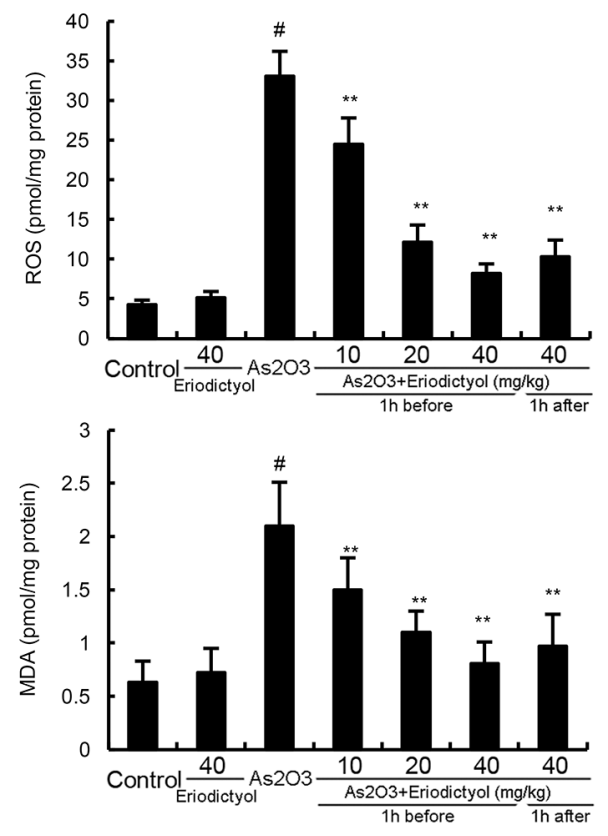

Figure 2: Effects of eriodictyol on $\mathrm{As}_{2} \mathrm{O}_{3}$-induced ROS and MDA levels. The values presented are the means \pm SEM ( $\mathrm{n}=12$ in each group). $\# \mathrm{p}<0.01$ vs. control group, ${ }^{*} \mathrm{p}<0.05$ and $* * \mathrm{p}<0.01$ vs. $\mathrm{As}_{2} \mathrm{O}_{3}$ group.
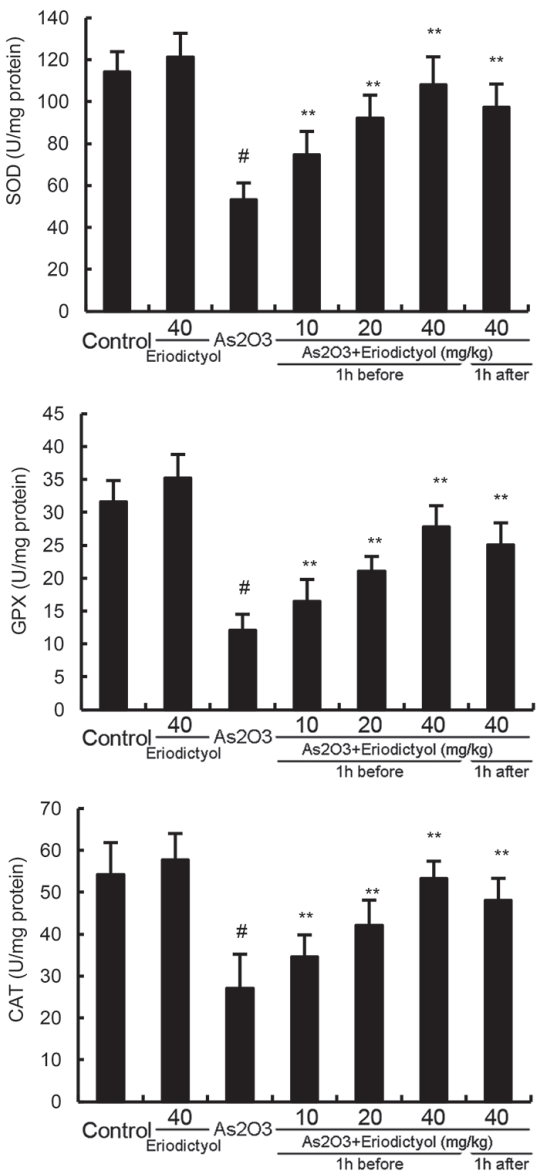

Figure 3: Effects of eriodictyol on $\mathrm{As}_{2} \mathrm{O}_{3}$-induced antioxidant enzymes SOD, GPX, and CAT activity. The values presented are the mean $\pm \operatorname{SEM}\left(\mathrm{n}=12\right.$ in each group). $\mathrm{p} \#<0.01$ vs. control group, $\mathrm{p}^{*}<0.05, \mathrm{p}^{* *}<0.01 \mathrm{vs}$. $\mathrm{As}_{2} \mathrm{O}_{3}$ group. 

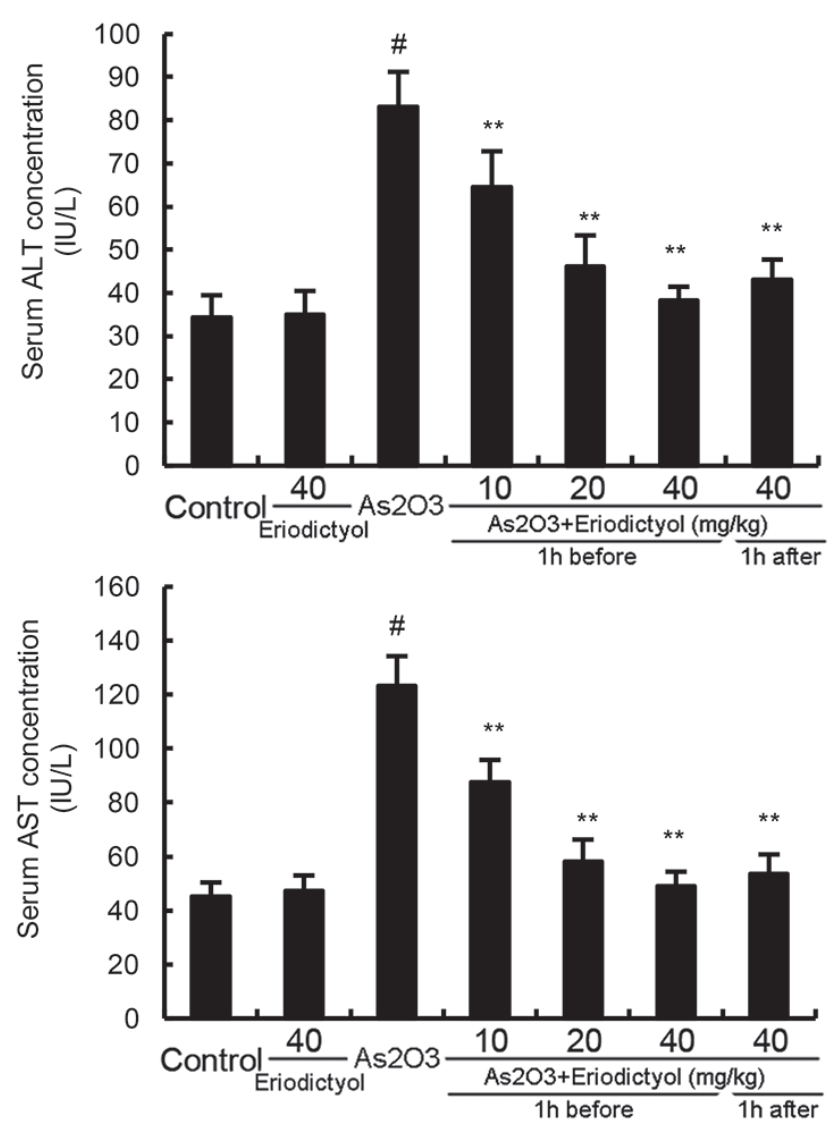

Figure 4: Effects of eriodictyol on $\mathrm{As}_{2} \mathrm{O}_{3}$-induced ALT and AST levels. The values presented are the means $\pm \operatorname{SEM}(\mathrm{n}=12$ in each group). $\# \mathrm{p}<0.01 v$ s. control group, ${ }^{*} \mathrm{p}<0.05$ and ${ }^{* *} \mathrm{p}<0.01$ vs. $\mathrm{As}_{2} \mathrm{O}_{3}$ group.

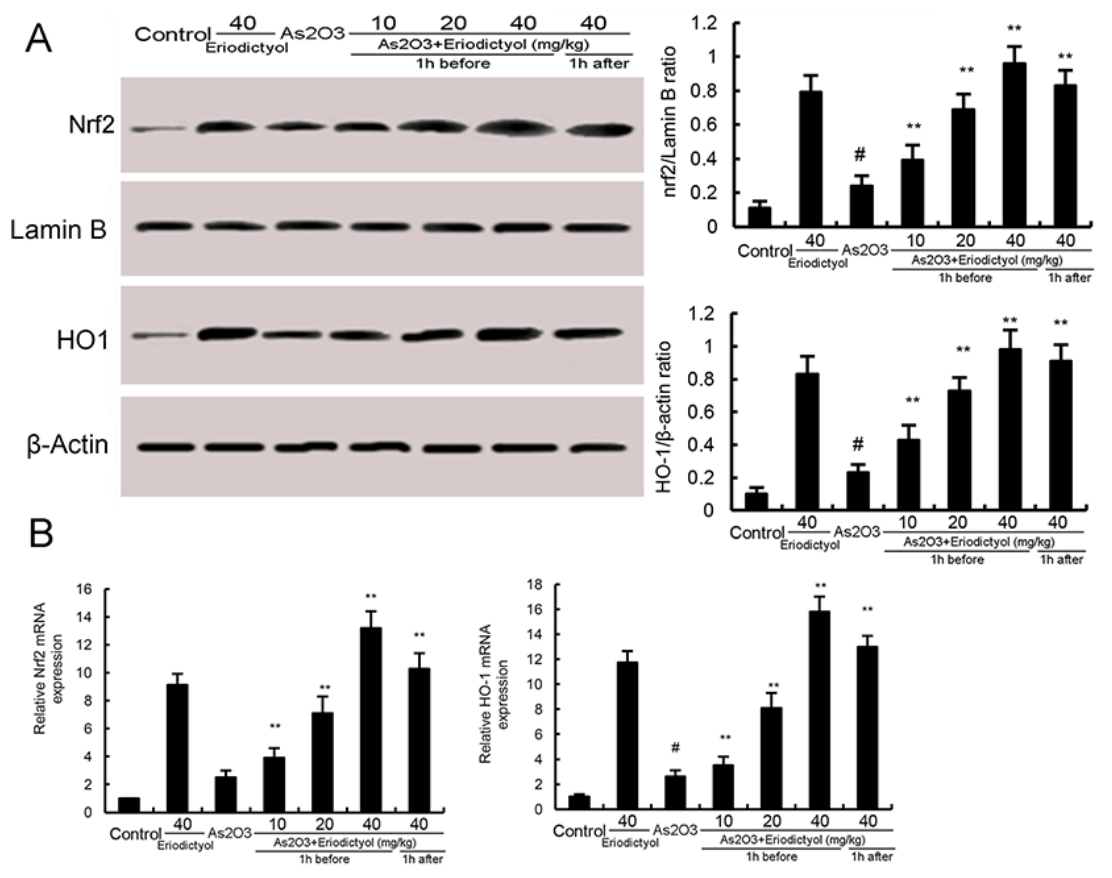

Figure 5: (A) Effects of eriodictyol on Nrf2 and HO-1 protein expression. (B) Effects of eriodictyol on Nrf2 and HO-1 mRNA expression. The values presented are the means $\pm \mathrm{SEM}$ ( $\mathrm{n}=12$ in each group). $\# \mathrm{p}<0.01$ vs. control group, ${ }^{*} \mathrm{p}<0.05$ and $* * \mathrm{p}<0.01$ vs. $\mathrm{As}_{2} \mathrm{O}_{3}$ group. 
drastically increase the cellular Nrf2 and $\mathrm{HO}-1$ expression even without the $\mathrm{As}_{2} \mathrm{O}_{3}$ induction (Figure 5).

\section{DISCUSSION}

Arsenic has been known to induce liver oxidative stress and liver injury. Eriodictyol, a flavonoid found in citrus fruits, has been reported to have antioxidant effect. In this study, we found that eriodictyol attenuated $\mathrm{As}_{2} \mathrm{O}_{3}$ induced oxidant injury in liver tissues by activating $\mathrm{Nrf2}$ / HO-1 signaling pathway.

Liver is the major target organ of many toxic chemicals [12]. The underlying mechanism of $\mathrm{As}_{2} \mathrm{O}_{3}$ induced liver injury has not yet completely understood. However, recent studies indicated that oxidative stress induced by $\mathrm{As}_{2} \mathrm{O}_{3}$ was the major reason that associated with liver injury $[13,14]$. A large number of studies showed that antioxidants had therapeutic effects against arsenic-induced tissues injury $[6,15]$. Eriodictyol has been reported to have antioxidant effect [16]. Thus, we detected the protective effects of eriodictyol on $\mathrm{As}_{2} \mathrm{O}_{3}$-induced liver injury. Our results showed that eriodictyol could attenuate $\mathrm{As}_{2} \mathrm{O}_{3}$-induced pathological changes of liver tissues. Serum ALT and AST were used as biochemical indicator of hepatic injury [17]. In this study, we found that eriodictyol inhibited $\mathrm{As}_{2} \mathrm{O}_{3}$-induced ALT and AST production. Taken together, these results suggested that eriodictyol exhibited protective effects of $\mathrm{As}_{2} \mathrm{O}_{3}$-induced liver injury.

Arsenic exposure exhibits oxidative stress by inducing the production of ROS in liver tissues [18]. In the present study, we found that the production of ROS increased significantly after arsenic exposure. MDA, a significant lipid peroxidation product, increases in oxidative stress [19]. It can be used to monitor the oxidative damage [20]. The levels of MDA in liver tissues increased significantly after arsenic exposure. However, treatment of eriodictyol remarkably suppressed $\mathrm{As}_{2} \mathrm{O}_{3}$ induced MDA and ROS production. Furthermore, the inhibition of SOD, GPX, and CAT activity by $\mathrm{As}_{2} \mathrm{O}_{3}$ was reversed by eriodictyol. These results demonstrated that eriodictyol reduced $\mathrm{As}_{2} \mathrm{O}_{3}$-induced oxidative stress and liver damage. Nrf-2, a basic leucine zipper transcription factor, has been reported to play critical roles in orchestrating cellular antioxidant defenses [21]. Activation of Nrf-2 leads to the expression of HO-1, a cytoprotective enzyme important in heme catabolism [22]. Previous studies showed that Nrf-2 can be used as an effective molecular target to counteract As-induced toxicity [23]. In this study, we found that eriodictyol up-regulated the expression of $\mathrm{Nrf2}$ and $\mathrm{HO}-1$ induced by $\mathrm{As}_{2} \mathrm{O}_{3}$.

In conclusion, our results demonstrated that eriodictyol had a protective effect on $\mathrm{As}_{2} \mathrm{O}_{3}$-induced liver injury. The possible mechanism is involved in activating Nrf2/HO-1 signaling pathway. Eriodictyol has a potential application to treat arsenic-induced toxicity.

\section{MATERIALS AND METHODS}

\section{Materials}

Eriodictyol (purity $>98 \%$ ) was obtained from the Department of Natural Products Chemistry of Shandong University (Jinan, China). $\mathrm{As}_{2} \mathrm{O}_{3}$ parenteral solution was purchased from Harbin Yida Pharmaceutical Company Ltd. (Harbin, China). GPX, SOD, CAT, and MDA kits were purchased from the Jiancheng Bioengineering Institute of Nanjing (Nanjing, China). The Nrf2, HO-1, Lamin B, $\beta$-actin, and horseradish peroxidase-conjugated (HRP) secondary antibodies were purchased from Cell Signaling Technology Inc (Beverly, MA).

\section{Animals}

Male Wistar rats ( 8 week old) were purchased from the Center of Experimental Animals of Jilin University (Changchun, China). All animals were housed in microisolator cages and fed standard laboratory chow and water ad libitum. The environment temperature was $25 \pm$ $2{ }^{\circ} \mathrm{C}$ and humidity was $55 \pm 5 \%$. All animal experiments were performed in accordance with the Health's Guide for the Care and Use of Laboratory Animals published by the US National Institute of Health.

\section{Experimental protocol}

Eighty-four rats were randomly divided into seven groups: control group, Eriodictyol alone treated group, $\mathrm{As}_{2} \mathrm{O}_{3}$ group, $\mathrm{As}_{2} \mathrm{O}_{3}+$ eriodictyol $(10,20,40 \mathrm{mg} /$ $\mathrm{kg}, 1 \mathrm{~h}$ before) treated groups, and $\mathrm{As}_{2} \mathrm{O}_{3}+$ eriodictyol $(40 \mathrm{mg} / \mathrm{kg}, 1 \mathrm{~h}$ after) treated group. Male Wistar rats were administrated $3 \mathrm{mg} / \mathrm{kg} \mathrm{As} \mathrm{O}_{3}$ intravenous injection at days $1,4,5$, and 7 . Eriodictyol was given by an intraperitoneal injection $1 \mathrm{~h}$ before or after $\mathrm{As}_{2} \mathrm{O}_{3}$ treatment. Control rats were treated with equal amount of $0.9 \%$ normal saline as a vehicle control. On the 8th day, the rats were killed and the blood samples and livers were collected.

\section{Histological analysis}

To evaluate the changes of liver issues, the livers were obtained and fixed in 10\% neutral buffered formalin overnight. The the tissues were dehydrated, paraffin embedded and sliced. The sections were stained with hematoxylin and eosin (H\&E) stain. Finally, the pathological changes of liver tissues were observed under a light microscope.

\section{Measurement of oxidative stress and antioxidant enzymes in liver tissues}

Liver tissues were homogenized and the levels of MDA, the antioxidant enzymes GPX, SOD, and CAT in liver tissues were tested by commercial kits (Jiancheng 
Bioengineering Institute of Nanjing, China) according to the manufacturer's instructions.

\section{Measurement of ALT an AST}

$24 \mathrm{~h}$ after the last time of $\mathrm{As}_{2} \mathrm{O}_{3}$ treatment, the blood samples were collected and centrifuged at 3000 $\mathrm{g}$ for $8 \mathrm{~min}$ to obtain the serum. Serum ALT and AST levels were measured by commercial kits (Jiancheng Bioengineering Institute of Nanjing, China) according to the manufacturer's instructions.

\section{Quantitative real-time PCR}

TRizol was used to extract the total RNA following the manufacturer's instructions (Invitrogen, Carlsbad, CA, USA). Then, the RNA samples were reversed transcription to cDNA with the Revert Aid First Strand cDNA Synthesis Kit (MBI Fermentas, Lithuania). Real-time PCR (RTPCR) was completed on a 7500 real-time PCR system (Applied Biosystems, Carlsbad, CA, USA). The primers were: Nrf2 (F: TTGTAGATGACCATGAGTC, R: TGTCC TGCTGTATGCTGCTT), HO-1 (F: TAAATGCAGTG TTGGCCCC, R: ATGTGCCAGGCATCTCCTT), $\beta$-actin (F: GGAGTACGATGAGTCCGGC, R: CGCAGCTCAG TAACAGTCC). Primers were acquired from Sangon Biotech Co. Ltd (Shanghai, China). The reaction conditions of PCR are as follows: $50{ }^{\circ} \mathrm{C}$ for $2 \mathrm{~min}$ and $95^{\circ} \mathrm{C}$ for $10 \mathrm{~min}$ followed by 40 cycles of $95^{\circ} \mathrm{C}$ for $15 \mathrm{~s}$ and $60{ }^{\circ} \mathrm{C}$ for $1 \mathrm{~min}$. Three replicates of every group were run.

\section{Western blot analysis}

Liver tissues were homogenized in liquid nitrogen and incubated in lysis buffer containing protease and phosphatase inhibitors (Roche, Basel, Switzerland) to obtain protein. The protein concentration was determined through BCA kits. Equal amounts of protein were separated by $12 \%$ SDS-PAGE gel and electrotransferred to a nitrocellulose membrane. The membrane was incubated with the primary antibodies Nrf-2 (1: 1000), HO-1 (1: 1000) at $4{ }^{\circ} \mathrm{C}$ overnight and then probed with HRP-conjugated secondary antibody at room temperature for $2 \mathrm{~h}$. The immunoreactive proteins were detected using an enhanced chemiluminescence Western blotting detection kit.

\section{Statistical analysis}

Data are presented as the mean \pm SEM. Comparisons between groups were analyzed using one-way ANOVA (Dunnett's $t$-test) and two tailed Student's $t$-test. The $\mathrm{P}<$ 0.05 or $\mathrm{P}<0.01$ were considered statistically significant.

\section{CONFLICTS OF INTEREST}

The authors have no conflicts of interest to declare.

\section{GRANT SUPPORT}

This study was supported by grants from the National Natural Science Foundation of China (No. 31672616).

\section{REFERENCES}

1. Peralta-Videa JR, Lopez ML, Narayan M, Saupe G, GardeaTorresdey J. The biochemistry of environmental heavy metal uptake by plants: implications for the food chain. Int J Biochem Cell Biol. 2009;41:1665-77.

2. Hughes MF. Arsenic toxicity and potential mechanisms of action. Toxicol Lett. 2002;133:1-16.

3. Kapaj S, Peterson H, Liber K, Bhattacharya P. Human health effects from chronic arsenic poisoning--a review. J Environ Sci Health A Tox Hazard Subst Environ Eng. 2006;41:2399-428.

4. Kitchin KT. Recent advances in arsenic carcinogenesis: modes of action, animal model systems, and methylated arsenic metabolites. Toxicol Appl Pharmacol. 2001;172:249-61.

5. Flora SJ. Arsenic-induced oxidative stress and its reversibility. Free Radic Biol Med. 2011;51:257-81.

6. Messarah M, Klibet F, Boumendjel A, Abdennour C, Bouzerna N, Boulakoud MS, El Feki A. Hepatoprotective role and antioxidant capacity of selenium on arsenicinduced liver injury in rats. Exp Toxicol Pathol. 2012;64:167-74.

7. Lee JM, Johnson JA. An important role of Nrf2-ARE pathway in the cellular defense mechanism. J Biochem Mol Biol. 2004;37:139-43.

8. Jiang T, Huang Z, Chan JY, Zhang DD. Nrf2 protects against As (III)-induced damage in mouse liver and bladder. Toxicol Appl Pharmacol. 2009;240:8-14.

9. Bucolo C, Leggio GM, Drago F, Salomone S. Eriodictyol prevents early retinal and plasma abnormalities in streptozotocin-induced diabetic rats. Biochem Pharmacol. 2012;84:88-92.

10. Sasaki N, Toda T, Kaneko T, Baba N, Matsuo M. Protective effects of flavonoids on the cytotoxicity of linoleic acid hydroperoxide toward rat pheochromocytoma PC12 cells. Chem Biol Interact. 2003;145:101-16.

11. Lee ER, Kim JH, Kang YJ, Cho SG. The anti-apoptotic and anti-oxidant effect of eriodictyol on UV-induced apoptosis in keratinocytes. Biol Pharm Bull. 2007;30:32-7.

12. Acosta D, Sorensen EM, Anuforo DC, Mitchell DB, Ramos $\mathrm{K}$, Santone KS, Smith MA. An in vitro approach to the study of target organ toxicity of drugs and chemicals. In Vitro Cell Dev Biol. 1985;21:495-504.

13. Jomova K, Jenisova Z, Feszterova M, Baros S, Liska J, Hudecova D, Rhodes CJ, Valko M. Arsenic: toxicity, oxidative stress and human disease. J Appl Toxicol. 2011;31:95-107. 
14. Hei TK, Filipic M. Role of oxidative damage in the genotoxicity of arsenic. Free Radic Biol Med. 2004;37:574-81.

15. Ghosh A, Mandal AK, Sarkar S, Panda S, Das N. Nanoencapsulation of quercetin enhances its dietary efficacy in combating arsenic-induced oxidative damage in liver and brain of rats. Life Sci. 2009;84:75-80.

16. Rossato MF, Trevisan G, Walker CI, Klafke JZ, de Oliveira AP, Villarinho JG, Zanon RB, Royes LF, Athayde ML, Gomez MV, Ferreira J. Eriodictyol: a flavonoid antagonist of the TRPV1 receptor with antioxidant activity. Biochem Pharmacol. 2011;81:544-51.

17. Ozer J, Ratner M, Shaw M, Bailey W, Schomaker S. The current state of serum biomarkers of hepatotoxicity. Toxicology. 2008;245:194-205.

18. Jomova K, Valko M. Advances in metal-induced oxidative stress and human disease. Toxicology. 2011;283:65-87.

19. Kadiiska MB, Gladen BC, Baird DD, Germolec D, Graham LB, Parker CE, Nyska A, Wachsman JT, Ames BN, Basu
S, Brot N, Fitzgerald GA, Floyd RA, et al. Biomarkers of oxidative stress study II: are oxidation products of lipids, proteins, and DNA markers of CCl4 poisoning? Free Radic Biol Med. 2005;38:698-710.

20. Halliwell B, Chirico S. Lipid peroxidation: its mechanism, measurement, and significance. Am $\mathrm{J}$ Clin Nutr. 1993;57:715S-24S; discussion 24S-25S.

21. Zoja C, Benigni A, Remuzzi G. The Nrf2 pathway in the progression of renal disease. Nephrol Dial Transplant. 2014;29:i19-i24.

22. Srisook K, Kim C, Cha YN. Molecular mechanisms involved in enhancing HO-1 expression: de-repression by heme and activation by Nrf2, the "one-two" punch. Antioxid Redox Signal. 2005;7:1674-87.

23. Pi J, Qu W, Reece JM, Kumagai Y, Waalkes MP. Transcription factor Nrf2 activation by inorganic arsenic in cultured keratinocytes: involvement of hydrogen peroxide. Exp Cell Res. 2003;290:234-45. 